\title{
POETIC METAPHORS OF LOVE IN ENGLISH AND VIETNAMESE
}

\author{
Phan Van Hoa ${ }^{*}$, , Ho Trinh Quynh Thu ${ }^{2}$ \\ ${ }^{1}$ University of Foreign Language Studies, the University of Da Nang, \\ Luong Nhu Hoc, Khue Trung, Cam Le, Danang, Vietnam. \\ ${ }^{2}$ The Department of Education and Training of Quang Nam, \\ Tran Phu, Tam Ky, Quang Nam, Vietnam
}

Received 14 September 2017

Revised 12 November 2017; Accepted 27 November 2017

\begin{abstract}
The conceptual metaphor theory states that poetic metaphors are in fact conventional metaphors but they are made novel via four techniques - elaboration, extending, questioning, and combination. Based on this sense, our paper focuses on examining and comparing poetic metaphors of romantic love in English to those in Vietnamese. Contrastive analysis is the main method applied in the study with the data for investigation coming from English and Vietnamese love poems. Also, the metaphor identification procedures by Pragglejaz Group and its extension are employed to minimize the risk of impulsiveness in metaphor collection process. Our findings reveal that the novelty of love metaphors in poetry does not lie in concepts but in linguistic expressions thanks to the four above techniques, among which combination is employed much more than the others in both languages. Furthermore, both conceptual and linguistic metaphors of love are found to be similar between English and Vietnamese poetry, which is supposed to result from the universality of metaphor. However, variations of cultures, lifestyles, and thought bring about some differences of love metaphors between these two languages.
\end{abstract}

Keywords: conceptual metaphor, poetic metaphor, metaphor of love, English, Vietnamese

\section{Introduction}

Love is a complex emotion but familiar and closely attached to human life. It is the endless source of inspiration to composers, especially poets. Love in poetry is diverse, plentiful, and mainly manifested by metaphors. Poetic language used to be regarded as unconventional, more imaginative and creative than daily language thanks to rhetoric, including metaphor. However, according to the conceptual metaphor theory, metaphor is pervasive in our everyday language. Poetic metaphorical expressions can be unconventional and novel; but the conceptual metaphor underlying them remains conventional and well-known to most

${ }^{*}$ Corresponding author. Tel.: 84-903581228

Email: hoauni@gmail.com people in the community (Kovecses, 2010). This matter is once again discussed in the paper where metaphorical expressions of love in English and Vietnamese modern poetry are investigated to find out how novel the poetic metaphors of love are in each language. Then, they are compared to draw out the universalities and variations of these metaphors between the two languages, English and Vietnamese. Although there are several kinds of love, our investigation focuses on just romantic love which is defined as a mix of emotional and sexual desire (Karandashev, 2015).

\section{Poetic metaphor}

Traditional views treating metaphor at linguistic levels show that metaphors in literature are more creative, unique, impressive, interesting, plentiful, and complex 
than those in non-literary texts (Semino \& Steen, 2008). It is believed that the "real" source of metaphor is in literature in general and in poetry in particular (Kovecses, 2010). Challenging traditional views of metaphor, the conceptual metaphor theory confirms the pervasiveness of metaphor in daily life. At the same time, it is said that the locus of metaphor is not just in language but in thought and action (Lakoff and Johnson 1980). The theory consequently distinguishes conceptual metaphors from linguistic metaphors. Conceptual metaphor (or metaphorical concept) refers to a mental representation describing the association of two different domains at an underlying cognitive level through the mapping SOURCE DOMAIN IS/AS TARGET DOMAIN. It is manifested in language by metaphorical expressions. Therefore, a metaphorical expression is a linguistic expression that is used to represent the conceptual metaphor in language. It is also called linguistic metaphor.

For metaphors in poetry, according to the conceptual metaphor theory, most of the poetic metaphors derive from everyday conventional metaphors; therefore, they are neither creative nor original nor imaginative. However, it is possible that the novelty lies in the poetic metaphorical expressions that are manifested in unconventional ways by using four techniques: elaboration, extending, questioning, and combination (Gibbs, 1994; Kovecses, 2010; Lakoff \& Turner, 1989).

(i) Elaboration employs already existing elements of the source domain in a new, unconventional way.

(ii) Extending is adding new elements to the source domain through new linguistic means to make the conventional metaphor novel.

(iii) Questioning is calling into question the very appropriateness or pointing out the inadequacy of our common everyday metaphors. (iv) Combination is the blending of different conventional conceptual metaphors in an expression.

These four techniques will be the foundation on which our investigation into poetic metaphors of love is based.

\section{Methodology}

Our comparative investigation into English and Vietnamese poetic metaphor of love is constructed by contrastive analysis which is defined as the scientific description and comparison of two or more languages to identify their similarities and differences. The study is carried out with the data collected from 500 love poems ( 250 poems in each language) composed from the early $20^{\text {th }}$ century to now. Linguistic metaphors are identified by using Pragglejaz Group (2007) and the extension of Pragglejaz's procedure including four steps: (1) Read the entire text-discourse to establish a general understanding of the meaning. Next, (2) determine the lexical units in the text-discourse. Then (3) take into account what comes before and after the lexical unit, determine if it has a more basic contemporary meaning in other contexts than the one in the given context. If yes, decide whether the contextual meaning contrasts with the basic meaning but can be understood in comparison with it. If yes, (4) mark the lexical unit as metaphorical.

According to Lado (1957, extracted from Johansson, 2008), the scope of a contrastive study includes a comparison of cultures. This step may be applied to make sense of the similarities and differences between English and Vietnamese poetic metaphors of love in our investigation.

\section{Novelty of love metaphors in English and Vietnamese poetry}

Investigating more than 500 English and Vietnamese poems, we discovered 3300 metaphorical expressions of love divided 
equally in two languages. They are distributed into 21 conceptual metaphors with the source domains of blindness, captive animal, climate, container, disease, drug, force, game, journey, life, living organism, magic, music, nutrient, object, opponent, plant, rapture, source of energy, time, and unity. Interestingly, a large amount of the novelty does not lie in conceptual but in linguistic metaphors. They are made new by using four techniques - elaboration, extending, questioning, and combination. Among these four techniques, combination is the technique that is employed the most frequently with 24.97 percent in English and 29.40 percent in Vietnamese. Three others account for 5.11 and 6.17 percent in English and Vietnamese respectively.

\subsection{Elaboration}

Elaboration is a principal mode of poetic thought that goes beyond the ordinary (Lakoff and Turner, 1989). It employs already existing elements of the source domains in a new, unconventional way with more detailed parts. Consider the following example,

(1) love tasted in tears/ is heady wine against sorrow. (Harris, Bittersweet)

"Wine" is defined as "an alcoholic drink" by Cambridge dictionary. This substance is a fluid applied to love description via the conventional conceptual metaphor LOVE AS A FLUID. The fluid of love here is presented clearly by the word wine, which is called elaboration technique in poetic metaphor. Furthermore, the love wine here becomes more detailed with the modifier heady which is explained as "having a powerful effect, making someone feel slightly drunk or excited" (ibid.). Depicted as heady wine, the expression of love is not just clear but unique. Following is another example.

(2) You've brought love/ in the Garden of Eden to my door. (Bryan, Eden in you)

According to Cambridge dictionary, the verb "bring" means "to take or carry someone or something to a place" while love is an abstract concept. As a result, the expression "bring love" is metaphorically interpreted via the conventional metaphor LOVE IS AN ENTITY. Moreover, the metaphorical expression of love in this case is elaborated by inserting the location of the entity (in the Garden of Eden) into the source domain, making the expression more detailed and hence novel. Similarly, the elaborating technique of poetic metaphor is also discovered in Vietnamese poetry.

(3) Anh có đi cùng em/ Đến những miền đất lạ/ Đến những mùa hái quả/ Đến những ngày thuoong yêu (Do you go with me to new places, to harvest seasons, to love days) (Xuân Quỳnh, Mùa hoa doi)

These lines express a love journey in which the partners are suggested travelling with each other (di cùng) to their common desired destination (đến... miền đất lạ, mùa hái quả, ngày yêu thuoong). LOVE - AS - A JOURNEY is a conventional metaphor in which the destination of the journey is correspondent to the common goal of the loving relationship. In this case, the destination of the love journey is elaborated via the expressions of miền đất lạ (new places), mùa hái quả (harvest seasons), and ngày yêu throong (loving days). With such manifestation, the love metaphor becomes more detailed; and the expressions of love are fine and novel. Let us look at another instance.

(4) Em ngon như rau cải/ Em ngọt như rau ngót./ Em giòn như cùi dừa. (You are as delicious as cabbage, sweet as sweet leaf, and crisp as copra) (Nguyễn Bính, Ái khanh hành)

The adjectives ngon (delicious), ngot (sweet), and giòn (crisp) are normally used to represent food flavour, taste, texture, and the like. Nonetheless in example 4, they are applied to describe the beloved and understood via the conventional metaphor LOVE AS A NUTRIENT. On the one hand, the love expressions here are not only comprehended by 
the adjectives ngon, ngot, giòn but also made clear and elaborate by the details compared rau cái (cabbage), rau ngót (sweet leaf), and cùi dìa (copra). On the other hand, although ngon, ngot, giòn are typical in food, these characteristics are not conventional in love expressions except ngot (sweetness). Obviously, deliciousness and crispness are new exploitation from the conventional source domain NUTRIENT of love to make the love expression novel and attractive. Moreover, the perception of partner as cabbage, sweet leaf, and copra is further a new discovery, showing the author's fine observation and wording. They are manifestations of another technique of poetic metaphor-extending, which is discussed in the next part.

\subsection{Extending}

As mentioned above, extending is the employment of new metaphorical expressions to make the conventional metaphors novel by exploiting new elements or aspects of the source domain. Let us consider the following verse.

(5) this is where love tends/ the flowers of desire,/ even the big smelly ones/ that bloom late at night. (Spring, Love doesn't care)

In these lines, love is conventionally represented as flowers that "bloom late at night". Talking about flowers' smell, people often think of its fragrance. However, the flowers of love here are not sweet-smelling but smelly or have an unpleasant smell, which brings the abnormality to the image of love flower. In addition, the description denotes that flower is always attractive though its smell is fragrant or malodorous. With smelly, the lines seem to send a message to the couples that love should always be respected at all costs. It may not be as perfect as expected but it is fruitful and acceptable. Following is another instance of using extending technique for love conventional metaphor.

(6) Love is a pair of handcuffs. (Miller, Excerpts from the lost dairy of the black Houdini)
The meaning of handcuffs is "metal rings that a police officer puts round a prisoner's wrists to stop them from using their hands or arms" (Macmillan dictionary). It depicts the unpleasant feelings of confinement that the partners experience in their relationship. Love is a pair of handcuffs is hence a metaphorical expression under the conventional metaphor LOVE IS AN OPPONENT. Yet, describing love as a pair of handcuffs is really unusual. This unconventional image is added to the source domain OPPONENT, helping the metaphorical expression unique. Such similar uniqueness is also found in Vietnamese.

(7) Một cành chụm nở hoa hai đoál Ôi cái đêm đầu hợp giữa ta. (Two flowers on a stalk bloom in our first night) (Xuân Diệu, Hoa ngoc trâm)

It is obviously seen that love in the lines is interpreted in terms of a plant with the expressions of đóa hoa (flower) and no (bloom). There is no newness when the source domain of a plant is applied to love representation. However, in this case, there is an unusual image, một cành - hai đóa hoa (two flowers on one stalk). It is a rare phenomenon in nature, an unconventional element that is exploited and added to the source domain PLANT of love, making the metaphorical expression of love original. Following is another instance.

(8) Em muốn thoát ral Trận bát quái tình yêu anh bày đặt/ Em tìm chóng mặt chẳng đường $r a$. (I want to escape from your labyrinthine battle array of love laid on the eight-sign figure's pattern but I cannot find the exit) (Hoàng Kim Dung, Lơ hẹn)

Love in the lines is conceptualized as a war underlying the expressions thoát ra (escape), trận bát quái (labyrinthine battle laid on the Bagua or Pa Kua eight trigrams pattern), and duoòng ra (exit). The metaphor LOVE AS A WAR is conventional but the expression trận bát quái tình yêu is unconventional. The 
image is a new discovery that is employed to describe a confusing situation in the loving relationship; at the same time, the partners also feel uncomfortable and worried about their relationship. It is obviously seen that the love expression, in this case, is really imaginative via extending technique.

\subsection{Questioning}

Besides elaboration and extending, another technique that makes conventional metaphors new in poetry is questioning. It indicates the problems or the doubt of the very appropriateness of the common metaphors.

(9) Gifts are not always free/ Burdens can be sources of intense pleasure [...]/ Love is a gift/ Each of us wants to know: Am I a burden or a gift? (Gordon, Gift are not always free)

Gift is commonly thought as "something good that you are grateful to have" while burden with the meaning of "something heavy that you have to carry" refers to a negative feeling that is difficult to deal with or to get rid of (Macmillan dictionary). Also in a common way of thought and expression, love is considered as a gift. However, the question here is that "gifts are not always free" and "burden can be sources of intense pleasure"; therefore, the partners have some doubt about the definition "love is a gift" and about their role, a gift or a burden, in the loving relationship. It is evident that the metaphoric images of love are not strange but the problem is pointed out here is really uncommon. A similar way of using love metaphors is found in Vietnamese poetry.

(10) Ví chăng nhớ có như tơ nhỉ/ Em thử quay xem được mấy vòng? (If love is silk, how much can you spin it?) (Nguyễn Bính, Nhớ)

According to Vietnamese dictionary, "nhớ" means thinking of someone or something with a great desire to meet them again. It is one of the manifestations of love that is represented as a silk thread in (10). In fact, sơi to (silk thread) is a popular and familiar image used for love in Vietnamese culture with the meaning of a linking or connecting thing. With such significance, the partners in the loving relationship are understood as being tied together by a silk thread. However, if it is a silk thread, it can be span. The calling into question if the silk thread of love could be span is against the common awareness of the silk thread in the loving relationship, creating a highlight of the expression, and making it novel.

Discussing the problem of the appropriateness of metaphors in poetry, poets do not only call into question but also give out a premise whereby the metaphor is interpreted. Let us look at the example below.

(11) Mùa hạ mát trong mưa/ Trái tim mát trong tình yêu ngọt lịm/ Những giọt tình đầu anh dành tặng riêng em (Summer is cool by rain. My heart is cooling in your sweet love. Your first drops of love is reserved just for me) (Nguyễn Vũ Thủy Tiên, Mura)

It is easy to see from the verse that love is metaphorized in terms of climate underlying the expression mát (cool). The description is a reference to the image of "mưa" (rain) mentioned in the previous line where the premise of the understanding the expressions of mát and giọt tinh (drops of love) in the next lines is pointed out. It is the way to eliminate the question of the appropriateness of using metaphors, an aspect of question technique mentioned above, helping metaphorical expressions to be apparent, and avoiding confusions for readers.

\subsection{Combination}

Combination is regarded as the most effective technique in making human everyday conceptual system rich and novel. It is triggered by using the materials of several conventional metaphors at the same time. For example,

(12) What happened to our love's a mystery/ I rummage through our empty past in vain (Gordon, I must accept but can't what cannot be)

Past is the period before and until, but not including, the present time. Past is time; but our past in (12) does not simply tell the 
past time. It is clearly employed to talk about love, which no longer exists. The love here is interpreted as time and expressed as the past that happened before the time of rummage. As "rummage" means "to search for something among a lot of other things", its appearance in the expression evokes an image of a container that is detailed via the information of its emptiness. The past time here is evidently understood in terms of a container and represented by the verb rummage and the adjective empty. So far, it can be seen obviously that love in (12) is comprehended via a combination of the metaphors LOVE IS TIME and LOVE (TIME) IS A CONTAINER. Similarly, combination of metaphors is found in Vietnamese poetry.

(13) Trời tình thơm mãi bao la,/ Đóa trăng rằm, vĩnh viễn hoa ái tình. (The sky of love is immense and fragrant forever; a full moon flower, the flower of love is everlasting) (Xuân Diệu, Aragông và Enxa)

Love in these two lines is successfully formed by a unique combination of several images such as trời tình, đóa trăng rằm, hoa ái tình with the qualities of being thom, bao la and vinh viễn, which may be interpreted as follows.

+ trời tình (the sky of love): LOVE AS A CONTAINER

+ đóa trăng rằm ( $\mathrm{a}$ full moon flower): THE MOON AS AN ENTITY, LOVE AS THE MOON, LOVE AS A PLANT

+ hoa ái tình (a flower of love): LOVE AS A PLANT

+ trời - trăng (sky - moon): LOVE AS A UNITY

+ thơm (fragrant), bao la (immense), vĩnh viễn (everlasting): LOVE AS AN ENTITY

Impressively, only in two lines of fourteen words, there are five conceptual metaphors used. Although they are completely conventional but their mixture makes the uniqueness of the expression, bringing the distinctive features to love that cannot be found in daily conventional language. It can be said that the image of flower used for love is not new in our language, but the way of using this image as in (13) is quite different, unconventional, more creative and perhaps more romantic.

In short, as an investigation based on poetry which is famous for the richness of imagination and creation, the metaphors of love are expected to be original and diverse. According to our findings from investigation, poetic metaphors are found to be new and imaginative in both English and Vietnamese. The novelty lies in the ways of expressing and using conceptual metaphors which bring new respiration, new life and new appearance to love and love expressions, helping to confirm the poets' talents.

\subsection{A comparison between English and}

Vietnamese poetic metaphors of love

The conceptual metaphor theory supposes that metaphor is universal, and the same metaphors can appear in different languages. This statement is once again reconfirmed in our investigation when almost all the conceptual metaphors of love are present in both English and Vietnamese poetry. For example, the LOVE AS A PLANT metaphor with the image of flower is applied to love description in these two languages, namely in examples 5 in English and 7 in Vietnamese. Moreover, as discussions above, the four techniques of making poetic metaphors novel are also found in these two languages. In addition, the combination technique is used the most frequently in both English and Vietnamese. However, as an investigation of metaphors expressed in different languages, it is expected to find out some differences between English and Vietnamese poetic metaphors of love.

Firstly, in spite of the same conceptual metaphors of love, a large part of metaphorical expressions are not the 
same. One of the typically differences in conceptualizing love between English and Vietnamese perhaps lies in the PLANT metaphor. Our findings show that the number of metaphorical expressions of love under PLANT metaphor in Vietnamese is 7.15 percent, nearly triple that of English (accounting for 2.61 percent). The phenomenon may be explained by cultural differences. Vietnam is a country of ricebased civilization (Trần Ngọc Thêm, 1996). The Vietnamese living environment closely attaches to their farmland, plants and crops. Consequently, these images are always in their minds and enter their linguistic expressions naturally. It is also the reason to account for some images just occurring in Vietnamese but not in English, such as rau cải (cabbage), rau ngót (sweet leaf), and cùi dìa (copra) in (4).

Secondly, all four techniques that make poetic metaphors of love more special than conventional metaphors are employed in both English and Vietnamese, but the ways of their manifestation are different. Returning to example 13, we can see that love here is conceptualized in terms of five source domains - container, plant, entity, moon and unity. Furthermore, just in an expression of three words, đóa trăng rằm (full moon flower) in the context of this example, there are three metaphors including THE MOON AS AN ENTITY, LOVE AS THE MOON, and LOVE AS A PLANT. In addition, besides the combination of several conceptual metaphors, the blending of several techniques is also discovered in Vietnamese love poetic metaphorical expressions, which is illustrated in example 4. Meanwhile, the combination technique in English is not as complex as in Vietnamese. It often consists of two metaphors underlying one expression like in example 12.

Thirdly, it is revealed from our data that the ratio of the novel metaphorical expressions is higher in Vietnamese with 35.57 percent than in English (making up 30.08 percent).

Finally, it is of questioning technique. It can be seen from example 11 that the appropriateness of metaphor is based on the premise given out before, which cannot be found in English poetry. Meantime, our data provide evidences for the existence of metaphors as premise for the understanding of the metaphorical expressions following; for example,

(14) Fire is love and love is fire;/ [...] This fire in our hearts that will burn forever... (Laset, Fire of love)

Obviously, the "fire burning in our hearts" expressed at the second part of the extract would not be comprehensible without the metaphorical expression "love is fire" under the LOVE AS FIRE metaphor. Regretfully, this phenomenon does not appear in our Vietnamese data.

In brief, poetic metaphors of love are found popular in both English and Vietnamese. They are similar in both conceptual metaphors and the ways of expressions via four techniques - elaboration, extending, questioning, and combination. However, deep in the language used for love, there are some differences. Some of them are emergent as the result of different cultures. Some others should be studied further to draw out a conclusion that can convince readers.

\section{Conclusion}

Our study of poetic metaphor of love is carried out in the light of the conceptual metaphor theory raised by Lakoff and Johnson (1980). The investigation shows much of the evidence of the strangeness or novelty of love metaphors in English and Vietnamese poetry. The novelty mainly lies in the expressions where four techniques - elaboration, extending, questioning, and combination are 
employed in both languages. Among these techniques, combination is emergent as the most forceful technique to make metaphorical expressions novel with the highest frequency of using. Thanks to metaphor, love becomes diverse. Thanks to these four techniques, the expressions of love are more attractive, creating fascination for readers. However, love metaphors manifested in terms of these techniques in each language are not quite similar between English and Vietnamese. It is possible that the distinctions in culture, lifestyle and thought are the causes of the differences in metaphorically expressing love between these two languages.

\section{References}

\section{Vietnamese}

Hoàng Phê (chủ biên) (2003). Tư điển tiếng Việt. In lần thứ 9 . Viện Ngôn ngữ học, Trung tâm từ điển học, NXB Đà Nẵng.

Trần Ngọc Thêm (1996). Tìm về bản sắc văn hóa Việt Nam. Thành phố Hồ Chí Minh: NXB Tổng hợp Thành phố Hồ Chí Minh.

\section{English}

Cambridge Advanced Learner's Dictionary (2005). $2^{\text {nd }}$ Edition. Cambridge University Press.

Gibbs R.W. (1994). The poetics of mind: Figurative thought, language, and understanding. Cambridge: Cambridge University Press.

Johansson, S. (2008). Contrastive analysis and learner language: A corpus-based approach. University of Oslo.

Karandashev, V. (2015). ACultural Perspective on Romantic Love. Online Readings in Psychology and Culture, 5(4). Available through https://doi.org/10.9707/23070919.1135. Access on June 27, 2016.

Kövecses Z. (2010). Metaphor: A Practical Introduction, $2^{\text {nd }}$ Ed.. Oxford: Oxford University Press.

Lakoff G. and Johnson M. (1980). Metaphors We Live By. Chicago and London: The University of Chicago Press.

Lakoff G. and Turner M. (1989). More Than Cool Reason: A Field Guide to Poetic Metaphor. Chicago: University of Chicago Press.

Macmillan Dictionary. (nd). http://www. macmillandictionary.com/dictionary/british/

Pragglejaz Group (2007). MIP: A method for identifying metaphorically used words in discourse. Metaphor and Symbol, 22(1), pp. 1-39.
Semino E. and Steen G. (2008). Metaphor in literature. In Gibbs R. (Ed.), Cambridge Handbook of Metaphor and Thought (p.232-246). Cambridge: Cambridge University Press.

\section{Sources of data}

\section{Vietnamese}

Nguyễn Bính (2005). Ái khanh hành. Tho tình Nguyễn Bính. Kiều Văn (tuyển chọn). NXB Đồng Nai. http://www.thivien.net/Nguyễn-Bính/Ái-khanhhành/poem-tWIJ_JcBg9FILAgkriOf3g.

Nguyễn Bính (2012). Nhớ. Tho Nguyễn Bính. Nguyễn Cừ (tổng hợp), p.37. NXB Văn học.

Xuân Diệu (2007). Hoa ngọc trâm. Xuân Diệu: Ông hoàng của tho tình yêu. Hà Minh Đức (tuyển chọn và giới thiệu), p. 242. NXB Giáo dục.

Xuân Diệu (2007). Aragông và Enxa. Xuân Diệu: Ông hoàng của tho tình yêu. Hà Minh Đức (tuyển chọn và giới thiệu), p.188. NXB Giáo dục

Hoàng Kim Dung (1994). Lỡ hẹn. Tho tình nũ thi sĩ Việt Nam. Kiều Văn (tuyển chọn), p.106. NXB Đồng Nai.

Xuân Quỳnh (1997). Mùa hoa doi. Tho Xuân Quỳnh. Kiều Văn. Nam Tuấn (tuyển chọn), p.33. NXB Đồng Nai.

Nguyễn Vũ Thủy Tiên (1994). Mưa. Tho tình nũ thi sĩ Việt Nam. Kiều Văn (tuyển chọn), p.49. NXB Đồng Nai

\section{English}

Bryan B. (2013). Eden In You... 'Yes. I love you'- Love poems. Vol.1. Retrieved November 11th. 2013 from http://www.passionup.com/eBooks/index.html

Gordon N. (2006). Gifts are not always free. Love poems, p.15. CafePress.com, USA.

Gordon N. (2006). I must accept but can't what cannot be. Love poems, p.34. CafePress.com, USA.

Harris A. (1990). Bittersweet. Inward in Words. Retrieved June 2nd. 2014 from http://www.alharris. com/Poems/love/bittersweet.htm

Laset J. (1999). Fire of love. Retrieved May. 25th. 2014 from http://www.netpoets.com/poems/ love/0928002.htm

Miller E. (2010). Excerpts from the lost dairy of the black Houdini. The ear is an organ made for love: poems by E. Ethelbert Miller, p.39. Retrieved October 14th. 2014 from http://www.eethelbertmiller.com/THE EAR_IS_AN_ORGAN_MADE_FOR_LOVE.pdf.

Spring J. (2014). Love doesn't care. Collected poems 1985-2014, p.120. Sarasota Poetry Theatre Press. 


\title{
ẨN DU THI CA TİNH YÊU TRONG TIẾNG ANH VÀ TIẾNG VIẸT
}

\author{
Phan Văn Hòa ${ }^{1}$, Hồ Trịnh Quỳnh Thư ${ }^{2}$ \\ ${ }^{1}$ Truoòng Đại học Ngoại ngũu, Đại học Đà Nã̃ng, \\ Lưong Nhũ Hộc, Khuê Trung, Cẩm Lệ, Đà Nã̃ng, Việt Nam \\ ${ }^{2}$ Sỏ Giáo dục và Đào tạo Quảng Nam, Trần Phú, Tam Kỳ, Quảng Nam, Việt Nam
}

Tóm tắt: Thuyết ẩn dụ ý niệm cho rằng ẩn dụ thi ca thực ra là ẩn dụ thông thường. Nhờ vào bốn kỹ xảo: trau chuốt, mở rộng, đặt vấn đề và kết hợp, chúng trở nên độc đáo mới lạ. Trên cơ sở đó, chúng tôi thực hiện khảo sát và so sánh các ẩn dụ tình yêu đôi lứa được thể hiện trong thơ tình giữa tiếng Anh và tiếng Việt. Phân tích đối chiếu là phương pháp chính dùng trong nghiên cứu này. Để giảm thiểu nhầm lẫn trong quá trình thu thập dữ liệu, chúng tôi sử dụng phương pháp xác định ẩn dụ của Pragglejaz Group. Kết quả thu được cho thấy sự độc đáo của các ẩn dụ tình yêu trong thơ không nằm ở ý niệm mà ở các diễn đạt ẩn dụ thông qua việc sử dụng bốn kỹ xảo này. Trong đó, kết hợp là kỹ xảo được dùng nhiều nhất ở cả hai ngôn ngữ. Đồng thời, chúng tôi cũng tìm thấy một số điểm tương đồng trong cả ý niệm và cách diễn đạt ẩn dụ thi ca tình yêu giữa tiếng Anh và tiếng Việt. Sự tương đồng này có thể do tính phổ quát của ẩn dụ. Tuy nhiên, các diễn đạt ẩn dụ này cũng có nhiều điểm khác nhau giữa hai ngôn ngữ do xuất phát từ các nền văn hóa khác nhau.

Tì khóa: ẩn dụ ý niệm, ẩn dụ thi ca, ẩn dụ tình yêu, tiếng Anh, tiếng Việt 